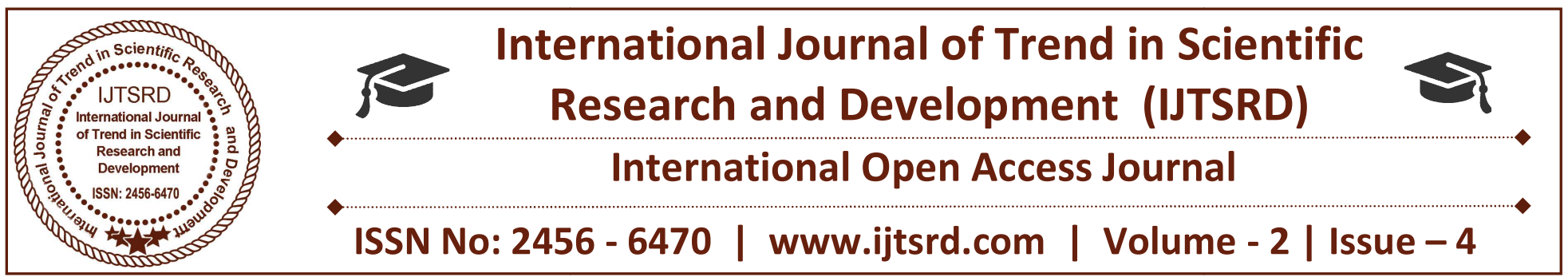

\title{
Representations of the Village through Religion and Society: A Study of Lalsalu(Tree Without Roots) by Syed Waliullah
}

\author{
Dr. Madhumita Chakrabarty \\ PhD, Research Scholar, Department of English, Central University of Karnataka, India
}

\section{ABSTRACT}

A community is a social category of people who shares common culture, common language or dialect, a common religion, a common norm, practices, customs and history. Harmony holds firmly together the various relationships of ethnic groups or institution in a detailed manner through the bonds of contrived structures, norms and values and religious belief. The term religion is also known as a social psychological condition. Not to mention, it serves a crucial role in controlling the belief system and cultural and social practice in a community. The chosen text is Lalsalu(Tree without Roots) by Syed Waliullah which was written before the partition of India and was published after it. The patriarchal power of the Bengali Muslim society of the 20th century has been represented by Majid. As the novel has showed us, the political, religious and social order of its making onto the community are imposed by patriarchal paradigms. Any challenge to such order is mercilessly counteracted. Consequently the protagonist of the novel in his clever dutiful role of a religious and holy man with aids from the patriarchal superstructures is able to create hegemony in Mahabbatpur, and capitalizes the religious faith of the poor villagers by establishing his spiritual monopoly. Thus the hegemony in various levels, such as religion, gender, and class are betrayed in the text and forms the matrix of the study.

Keywords: Religion, Community, Patriarchy, Hegemony

\section{INTRODUCTION}

Village as a category is associated with a whole lot of other social categories like community, society, people with their unique culture and tradition. Village is considered as a unit for administrative and demographic purposes. In fact the definition of 'Village' depends on how we approach it. In other words perspective plays a vital role in understanding village. If we look at the etymology of "village", we could see that the origin of the word is traced back to Latin word 'Villa' meaning 'country house' and then in the late $14^{\text {th }}$ century as a part of Late middle English the word was first quoted and used as "houses and other buildings in a group or an inhabited place larger than a hamlet but smaller than a town". So the term Village is associated with Home and its people, the community to be more precise. And with community come their tradition and rituals, their festivals and celebrations, language and other modes of expression, the economic and social condition, imbricated with caste discrimination and religion and the way it controls their modes of expression and everyday life.

If we speak about villages of India, religions not only have been serving as the foundation of our culture, but have had huge effect on Indian political affairs and the social order. India is characterized by more ethnic and religious groups than most other countries of the world. It is characterized by a diversity of religious beliefs and practices. Harmony holds firmly together the various relationships of ethnic groups or institution in a detailed manner through the bonds of contrived structures, norms and values. According to Emile Durkheim "Religion is a unified system of beliefs and practices relative to sacred thing which 
unite in to one single moral community." However, harmony and unity do not mean uniformity which implies similarity; unity may be born out of similarity. In Macionis John's definition, "ethnos in the narrow meaning of word in the most general form can be defined as a historically formed community of the people possessing common relatively stable, specific features of culture as well being aware of their unity and difference from their communities". They also have a realization of their own culture bond. India is an ethnological museum. "M.N.Srinivas observes that the unity of India is essentially a religious one. People may worship different deities but the religious scriptures - Puranas, Brahmanas, Epics and Vedas knit the numerous heterogeneous groups together into one religious society and give them the sense that their country is sacred. Religious aspect is one the most important and influential in human social life. But the point that is very much noticeable is that religion is probably the most powerful instrument of social control. Religion, based on the cultural needs of men has added new dimensions to human life and human development. When coming down to the concept of religion in Indian rural society and its practice, then it must be said that there are distinctions in the ways and religious beliefs in the villages. If we are to reclassify the Indian traditions and the complex model of Indo-Islamic formation then we have to capture the nuances of Indian Islam and rework the paradigm of the 'great' and 'little' traditions. For as Dipesh Chakrabarty says with regard to Bengali literary Nationalist culture that emerged in the Nineteenth Century and intensified in the wake of Swadeshi Movement:

"[There is] a fundamental problem in the history of this modern Bengali nationality - the fact that this nationalist construction of home is a Hindu home. It is not that the Muslim did not share any of this language ... [but] Hindu nationalism had created a sense of home that combined the sacred with the beautiful. And even though, this sense of home embodies notions of the sacred, it was not intolerant of Muslims as such. The Muslim - that is, the non-Muslim league Muslim, the Muslim who did not demand Pakistan had a place in it. But the home was still a Hindu home; its sense of the sacred was constructed through an idiom that was recognizably Hindu."

The case of Bengali-Muslims presents itself, in this context, as being somewhat unique as it both conform to and deviate from the general pattern of development in south-Asian Islam. The emergence of a sharper, stronger sense of a collective Muslim identity and its close and direct bearings on the cultural growth are matters of common concern among the students of cultural studies of South Asian Islam identity. The Bengal phenomenon does not, however, reveal a uniform and unidirectional search for an exclusive Islamic identity. The Bengal Muslim search for a collective identity was clearly caught between the two opposite pulls of a local geographical Bengali culture and of an extra-territorial Islamic ideology. Indeed, a close analysis of the MuslimBengali literature in the late Nineteenth and Early Twentieth Century reveals, however, unmistakable tensions and vacillations and even clear conflicts in Bengal Muslim's self-perceptions and self-statements, uncertainties that one may also detect in the complex and dissimilar patterns of modern Muslim conditions in Bengal. It would be unrealistic though, to take the issue of religion completely out of the equation. Bengali Muslims have been trying to construct a synthesis of their identity for over a hundred years now. During the partition of 1947, when the East part of Bengal became Bangladesh, they created an identity on the premise of excluding "Hindu India" as the other. They were Muslims then. Then came a time when being Muslim was not enough to hold the homogeneity of Pakistan. They found themselves under yet another colonial rule. The dream of a free Bengal, 'Shonar Bangla' Bangladesh was in the making. Finally they broke free in 1971, this time their identity was primarily constructed on the premise of excluding "Muslim Pakistan" and thus they became "secular Bangladesh". The story is, however, a continuing one.

The text that is chosen for this particular study is Lalsalu(Tree Without Roots) by Syed Walliullah.

\section{Theme of the Text in Reference}

Before Syed Waliullah (1922-1971) Lalsalu (1948), the history of novels of Bangladesh was not very significant. Based on the novel Lalshalu (Tree without Roots) written by Syed Waliullah and published in 1948, is perhaps the most significant novel about the rural Muslim community of East Bengal (Bangladesh). The brief storyline is;

In a remote agrarian village, suddenly a haggardlooking Mullah named Majid appears. He cleans up an old dilapidated grave and by declaring it as the shrine of a famous Pir (a holy man) begins to worship it. The villagers, of course, have no clue who the holy 
man was, and though it is a hoax, gradually give in and begin to believe in the myth. The mystery of the grave, the red fabric spread over its oval shape, the glowing candles and the Quranic chants that Majid recites beside the grave; create such an aura in the ambience that the villagers, mostly simple peasants, completely succumb to Majid's spell. They start to bring rice and money as offerings to the "holy shrine". The shrine, through all these years, supplies Majid not only financial independence but psychological control over the people as well. From a vagabond desperado, he becomes a man well rooted in society. He marries Rahima, a not-so-young but hard working peasant woman who though robustly built, remains a docile wife. But as Majid's wealth and power increase he feels the need of a younger wife. He marries Jamila, a teenage girl who has no fear either for the grave or for Majid himself. Majid vulnerably stays smitten to his youthful sexy wife and slowly loses his tranquillity and the myth about the 'holy' grave becomes threatened. Jamila, inadvertently, becomes the nemesis for Majid. And Mother Nature, in the form of a deluge, finally strikes as Majid oversteps the boundary of humanity.

\section{The Original Author and His Times}

Syed Waliullah (August 15, 1922 - October 10, 1971) was a Bangladeshi novelist, short-story writer and playwright. He was notable for his debut novel, Lalsalu (translated in English with the title "Tree Without Roots"). He was awarded Bangla Academy Literary Award (1961), Ekushey Padak(1984) and Bangladesh National Film for Best Story (2001).

Lalshalu was written before the partition of India and was published after that historic event. Right before the partition when there arose a high voice in favor of an independent state for the Muslims, Waliullah was trying to detect the falsity in pseudo-religious dogmas and practices, which voiced against freethinking and education. It is also worthy to mention that as the settlement of Pakistan was on the basis of religious rights, Lalshalu could not draw the attention of the Bangla Muslim literature. Only after the second edition of it in 1960 Lalshalu began to be popular. It is possibly the most significant novel about the rural Muslim community of East Bengal (Bangladesh).

Tree Without Roots, actually a transcreation by Waliullah himself which has been pleasingly accepted as "enhanced version" or a more mature work of the author was written in English nineteen years after the
Bangla version Lalsalu. Syed Waliullah, being a part of the post-war intellectual commune, instills the theory of existentialist view as well as futuristic elements in his writing. He coalesce existentialist approach of meaninglessness of a human existence and the modernistic idea of self-consciousness side by side. He neither endorses a sense of total rebuff of existence nor gives a hope either. Instead he chooses to hang about in between two ambiguities. In a way, the novel combines elements of both modernism and existentialism.

\section{Deconstruction of the Novel and the Relevance of the Study}

In Lalshalu, Syed Waliullah has portrayed the traditional superstitious Muslim society of Bangla through the story of Majid and the ancient tomb covered with a lal (red) shalu (cotton fabric). Majid, an outsider of the village Mohabbatpur, arrives one day and announces that the uncared-for tomb is of a great priest of high honor which causes a sort of fear among the populace of the village and thus taking after the responsibility of looking after the tomb, Majid begins his establishment for livelihood. Whenever there appears any sign of obstruction on the way of Majid's existence, he creates a circle of fear to mitigate the village people. Sometimes his existence is endangered from his own conscience also.

The patriarchal power of the Bengali Muslim society of the 20th century has been represented by Majid. As the novel has showed us, the political, religious and social order of its making onto the community are imposed by patriarchal paradigms. Any challenge to such order is mercilessly counteracted. Consequently the protagonist of the novel in his clever dutiful role of a religious and holy man with aids from the patriarchal superstructures is able to create hegemony in Mahabbatpur, whereas his wives continue their subalternity. After agreement, Majid marries twice: first the widow, Rahima who is 'wide hipped, strong and beautiful'; and then, the young, lively and curious one, Jamila. Rahima and Jamila invoke the memory of the prophet's two wives. . In the post-Hijri period of his life the Prophet too married two women, viz. Sawda and Ayesha: the elderly Sawda was suitable to take care of the family and the younger Ayesha remained under their care. Nonetheless, such parallelism appears only to be the novelist's motif to highlight his analysis of the political context in which religion was being used to force a division on people who were otherwise not bothered by differences. The 
agenda of re-appropriating the existing patriarchal religious hegemony to launch a counter-offensive, exemplifying competitive patriarchy is represented by Majid's intention of offering 'divine' service to this community. Thereafter, Mahabbatpur becomes a site of contesting patriarchal practices where them, first pushed already to the corner and afterwards marginalized, are not allowed to speak but only to be spoken for or be represented by.

In the name of religious belief, Majid has tried to grab whatever he needs. From financial assurance, he once upon a time proceeds to satiate his subconscious desire also. As a result, Rahima comes in his house as his wife but after some years he feels that the single wife is not enough for him. He begins to visualize the physical features of Hasunir Ma who helps Rahima in her household chores or of the wife of Byapari. As a consequence we get the arrival of Jamila as Majid's second wife. When most of the people of the village fail to earn the minimal livelihood, no sort of want can touch Majid. From every effort of him, he only ensures about it very intentionally.

Women, however, remain irrelevant in this debate. Notably, this incident takes place to diffuse the tragic overtone of the forced divorce between Khalek Byapari, the richest man in the village and his first wife Amina for her alleged 'infertility.' In reality Majid had started to yearn for her and so/he manipulated this divorce solely based on his voluntary verdict. Majid declared her as 'fallen' and therefore unfit as Byapari's wife. Amina was forced to leave her own family. This event caused instigation in several cases where the husbands on grounds of suspected 'chastity deserted their supposedly 'infertile' wives. These manipulations were implemented amidst formidable silence and with calculated precision. Majid as a self-proclaimed religious leader had imposed certain codes of conduct onto the community. Yet, his second wife, Jamila seriously confronts this order and threatens Majid so much that she is physically stifled and left to die. Nevertheless even in her death she threatens Majid's authority - the feet of her dead body was perched vandalizing the sanctum sanctorum of Majid's place of worship. Patriarchal violence seems to be at a loss and somewhat embarrassed when confronted with such silent yet visible defiance.

The fear that Majid created since his emergence in the village continues till the end of the novel. Whenever Majid feels necessity, he sharpens that sword of fear creating different spells. Regarding the traditional practices and beliefs of the villagers, Majid preaches of his own keeping pace with the holy books. The incident in which Maid compelled an elderly boy and his father to be circumcised contributes hugely in Majid's enterprise. Convincing Byapari to divorce his first wife Amina Bibi and compelling him it do it; Majid matures his own plans only. When Akhas Ali tries to set up a school in the village, Majid bravely meets the challenge and establishes his opinion that a mosque is far more essential. Two cases that make him perplexed are the arrival of Peer Shahib in a neighboring village and the apparently anti-religious behavior of Jamila. Due to the appearance of the Peer Shahib Majid falls in a sort of footless situation which instigates him to tackle the perilous situation at a great risk. For that turn Majid survives but what does he do regarding Jamila?

At first Jamila seemed to Majid a soft lump though from Jamila's part he was not the same because on the day before marriage Majid goes to have a look at his would-be-wife, he seemed as the father of the future groom to Jamila. Moreover, the days he comes to his house, Rahima seems to her as the mother of the groom. Through these humorous references, Waliullah has depicted the tragedy of Muslim Bangla. After some days of the marriage, Majid discovers that Jamila is not that much submissive, she does not possess any fear in the name of religion; she is stubborn and does whatever she considers better; she denies all the shackles that Majid wants to give her. To exhort his influence on her, one night he locks her in the tomb-shade. The night becomes stormy, as there is storm is Majid's own soul. After the storm when he opens the entrance of the tomb-shade, he discovers the unconscious body of Jamila, lying flat on back, having no cloths on her chest; and touching the tomb with her feet.

Subsequently, Mahabbatpur turns out to be a place of disputed patriarchal exercises.

The design of the fiction has been captured in period of time in East Bengal right after the Independence of India and the partition of undivided Bengal which is going through social changes and modernization. Majid is the representative of the patriarchal order of the pre-colonial society whereas Akkas Ali is the agent of the postcolonial society endowed with modern education, and urban polish. Their interests collide around the dispute over the contradictory proposal to build a mosque for the spiritual 
upgradation in Mahabbatpur and a secular English school (though there were two maqtab ${ }^{10}$ ). Majid obtains better support among the villagers in favor of a mosque and defeats Akkas on basis of faith and religious sentiment.

Majid was often portrayed as a modern-hero by Waliullah. He has got the mental conflict, the consciousness and the existential crisis of a modern man. He earns the reader's sympathy even though he is a fake religious guru. After he has been long fighting from his childhood with paucity, starvation and uncertainty, he arrives at Mahabbatpur. He never had any home of his own. He has always dreamt of a home, wife and economic stability. But his fate before here never supported him to have a smooth and welloff life. Majid is not a bizarre hero instead, a person who uses religious superstition to stretch his roots among the ordinary villagers. Slowly he becomes powerful, authoritative, prominent and controlling. He does not only have the benefit of financial steadiness but also takes pleasure of being authoritative and apparently reliable. This new taste makes him the slave of his self-created sham identity. His divergence as a modern man is representative of the social conflicts which is going through transition of social order and the new rootless existence which is the gift of modernization and so called development of the post Independent and post colonial timeframe which has been captured by Waliullah.

Lalshalu was composed before the partition of India and was in print after that historic event. Right before the partition when there arose a high voice in favor of an independent state for the Muslims, Waliullah was trying to detect the falsity in pseudo-religious dogmas and practices, which voiced against freethinking and education. Lalshalu has become a true picturization of the agrarian Muslim society. From this novel the early superstitious scenario of a Muslim Bangla village could be visualized.

In the English version, now generally believed to be by Syed Waliullah himself, Majeed acquires certain grandeur at the end, returning alone to the mazar in the midst of raging flood waters. A picture of rural Bangladesh in the early forties, Tree without Roots also provides a picture of eternal Bangladesh subject to the ravages of nature, of storms and floods, of cyclones and dying rivers.

Waliullah has created a fictional village Mahabbatpur, as the theatre for the doings of the fortune-hunting
Majeed who has transformed into a shrine the hitherto neglected grave of an unknown person about whose identity he knows nothing but whom he declares to be a saint that has visited Majeed in a dream. The village is almost mythical; it is without connection with the world outside; Life here is elemental. Majeed is a veritable colonialist and an active missionary, two rolled into one. He plants fear into the hearts of the innocent peasants, makes them feel guilty for their neglect of the patron saint. He becomes the ruler and seeks to transform the simple peasants, almost pagans in their lifestyle, into devout Muslims. But in spite of all this the author does not make him the villain of the piece, $\mathrm{He}$ is as lonely as the shrine he has created and with time he himself has become the slave of his own creation. He is nostalgic; he feels for his childhood home which he has left and tries to strike roots in a land where he has never been before. Having no sharer of his secrets he often resorts to memory and recollections of his past days and past life where he was nobody, a victim of poverty and misfortune. And how he preyed upon the simple rural folk by exploiting religion, becoming the self-appointed guardian of a mazar which he claims is that of a saint. Majeed could leave his shrine for his safety but he did not because his identity has no meaning without the shrine. He mingles his past and present, his happiness and sadness, he is a modern character:

That wilderness day when I first came to this village how hungry I was! I used to have nothing that time, neither owned any land, home, nor wife and cattle. And now I am the protector of the mazar. I get money, $I$ reside contentedly, and I demand the people's admiration. Of course I have changed but, thanks be to God, for the better. I have no cause to be sad (Waliullah 76).

Now, it is not only his material subsistence but also his values, belief-system that have to to live on. Nevertheless he is deeply conscious of the fact that the mazar is a sham and pointless entity, he seizes this purposelessness which can only make his future existence significant. Alternatively, it is Majid's image and personality which insists his realization to build a significance and worth which can sustain his mature and continued survival in Mahabbatpur. It is his survival which comes first of all, even his ethics. Even he tells to himself: "If, I make a living, at the same time, is there something immoral in that? After all one must live. And I live to spread the word of God" (waliullah 12). Seen in that way, Majeed is a representative of coarse deprived pitiable Bangladeshi 
country people who hunt for their existence in selfconstructed sacred identity. As a substitute of their ruthless poverty, they must exist but for the survival they need to have some kind of ethics to embrace or to turn their life consequential. In the words of the narrator of the novel:

Perhaps the reason there are so many white tupees in this part of the world is that the land cannot feed the men. Little food means more religion. God said: cover your heads when you pray to me, for this is the mark of the god-fearing man. . . There are more tupees than heads of cattle, more tupees than sheaves of rice (Waliullah 5).

It is also somewhere true that the past memories of Majeed does not give him pleasure, they are mostly the source of fear. He is afraid of his past or rather going to back to the Past. Incident explains that he has robustly resolute to go back in his shrine "at the cost of his own demolition even" (Waliullah 135). Majeed proves himself as his own master by applying his own subjective choice. Actually, he does not have any identity without the shrine. Maybe the shrine is a sham but it is the only point to continue his life. Though, Majeed knows that his return may bring his life at risk, he decides to uphold his value or essence as his identity will not have any meaning (here value or power) without his essence. As a result his existence at a definite end of life without his worth (essence) is also futile. An unease or fright of being defeated his core or belief is the cause behind this. As an alternative to any Pir, it is flood or natural calamity that brings worry back inside Majeed to smash his self-constructed worth:

"It is tricky for one to know whether one has sinned, and to what degree, Majeed told himself. Except I do identify that I am not terrified for the reason of my misdeeds. My fright is of having to return to where I began" (Waliullah, 134).

Most likely it is the motive why Majeed chooses to put his life at jeopardy with the optimism of retaining all his material accomplishment he has achieved in Mahabbatpur. Perhaps he doubts his past poor powerless life. Now he knows that both of his past and present lives are meaningless but with he has chosen his present life as more important. Having said that it is equally true Majeed is not an absurd hero but a person who uses religious superstition to extend his sources amidst the ordinary village dwellers. Slowly he turns out to be prominent, authoritative and controlling. He does not only takes pleasure in financial steadiness but also enjoys being reliable. This new experience makes him the slave of his selfcrafted fraud character that he constructed for himself. His reappearance is a pick of giving in towards his own dignity.

\section{CONCLUSION}

Literary imagination plays a vital role in a process of recovery where Hindus and/or Muslims attempt to map the contours of the mutilated land in a bid to create a site of belonging, habitation and memory while changing the dynamics of fiction, particularly the form and content of the novel in Bangla that has responded to 1947 and afterwards in heterogeneous ways. When the recent partition destroyed a sense of belonging to the land, these texts offered a renewed sense of place that contributed to the processes of decolonization and reinstated the 'human subject' at a time when it was most dehumanized. As Lacan (and Freud before him) has reminded people, the event of trauma, by its very ambiguous nature, recedes to the background while fantasies based on it overpower individual and collective psyches. This literary piece forms a testimonial or memory-text that deals with the construction of the Muslim subjectivities in times of the partition of Bengal and right after that and the questions around religion, faith, the belief-system, the complex collaboration of poverty and religion especially the lower caste, the rural community. Texts that deals with these wide ranging issues, written over a long period of time, try to reconstruct the lives of individuals and communities, marginal or elite, whose memories of trauma and displacement had dissociated them from their own life stories. The less visible and delayed effects of displacement and violence are seen in the family and community spaces that these texts foreground. They give an added dimension to a set of micro-events, often unspeakable, within the partition and lay bare the processes of how literature transforms the actual into the apocryphal and the mythical.

On one hand, the text has recognized and documented conflicts and identity crisis to see the importance of personal memory to demonstrate the plurality of how one remembers the incidents that causes the sociocultural change (or how one forgets it) even within the similar commune just as they display that gender, class and caste variegate the recollections of a community since the communities in turn suffers a process of self-fashioning at definite moments in their 
history. A call for new resources for remembering and representing these incidents means that social relations, locality as well as memory that makes up subjectivity. Thus, one needs to investigate how both the ideological force of the present/past relationship as well as the tension with which the author, reader and text are held together as historical variables have produced the cultural and memory-texts in the region. The novel is significant, not for the reason that it signifies someone's destiny to us, possibly moralistically, but because this outsider's luck by virtue of the flare which devours it yield us the warmth which we never draw from our fate.

Finally, the word 'Lalsalu' means 'red cloth' which generally is used on a religious shrine. This title in Bengali itself serves as a symbol of religious impact on the narrative. In fact, it is known that the novel in Bengali was inspired by a shrine covered with red cloth that he would often pass when he lived with his father in Mymensingh (presently in Bangladesh). Although, the English translated version of the text does not retain the same title, it reflects the same storyline employing the 'shrine' as a significant motif that is used in the whole narrative. It becomes the symbol which represents the religion and its overwhelming influence into the minds of the simple rustic people. It also stands out as a symbol of power which was acquired by Majid in order to dictate the commoners in Mahabbatpur. Needless to say, the same motif served as an instrument of fear exploited by the name of religion or religious faith by Majid to control their lives and ensure his survival in the village.

\section{REFERENCES}

1. Waliullah, Syed, Tree Without Roots. 2006, Calcutta: Ubs Publisher's

2. Bose, N.K. The Structure of Hindu Society, New Delhi: Orient Longman.1975

3. Srinivas, M.N. Village India, Chicago, Chicago University Press, 1967: pp 1-35; M.N Srinivas. The Remembered Village, Delhi, Oxford University Press, 1976

4. Dubey, S.C. "The Indian Village: A Symposium", Journal of Asian Studies, vol.16, New York: AMS Press, 1956-57: pp.19-30.

5. Inden ,Ronald B.Imagining India, Oxford: Basil Blackwell, 1990
6. Kohli, Atul. The State and Poverty in India: The Politics of Reform, Cambridge: Cambridge University Press, 1987

7. Rigg, Jonathan, "Redefining the Village and Rural Life: Lessons from South-East Asia" (Source: The Geographical Journal). 1994 : The Royal Geographical Society, Vol. 160

8. Patel, Sujata, "The Nostalgia for the Village: M.N. Srinivas and the Making of Indian Social Anthropology". Journal of south-Asian Studies, 1998

9. Dasgupta, Biplab, "Urbanization and Rural Change in West Bengal." February 14: Economic and Political Weekly,1987

10. Park, Robert E. Human Communities, New York: Free Press, 1952:p.16.

11. Breman, J. The Scattered Image: Construction and De-construction of the Village in Colonial Asia. Amsterdam, Comparative Asian Studies, 1987 --- The Village in Asia Revisited. Delhi, Oxford UP, 1997

12. DeVotta, Neil. "The Utilisation of ReligioLinguistic Identities by the Bengalis: Towards General Explanation." Commonwealth and Comparative Politics 39 (2001): 65-95. 